\title{
A novel population of composite mounds: their initiation, growth and demise. San Emiliano Formation, Cantabrian Mountains, Spain
}

\author{
Steven L. Rogers ${ }^{1}$ (D)
}

Received: 22 January 2018 / Accepted: 19 February 2018 / Published online: 28 March 2018

(c) The Author(s) 2018

\begin{abstract}
Purpose Mounds from the Pennsylvanian aged San Emiliano Formation (Cantabrian Mountains, Spain) are commonly well exposed. These mounds range from 2 to $50 \mathrm{~m}$ in height and are observed to be primary geological features. The mounds are described and classified and the factors and controls of mound nucleation, growth and demise have been established. Methods Microfacies analysis of 177 thin sections has revealed the composition of the mounds and surrounding carbonates. Results Composite mounds, exhibiting characteristic components of both Cluster mounds and Agglutinated Microbial mounds are described. The mounds are skeletal-microbial/pack-wackestones. Peloidal, homogenous and clotted micrites are the main sedimentological constituents of the mounds. Microfossils are dominant with Donezella, Claracrusta, Rothpletzella and Girvanella being common. Small foraminifera, bryozoans, corals and algae are all present within the mounds, but are more common within off-mound carbonates.

Conclusions The formation of the mounds was controlled by a dynamic relationship between Donezellacean algae, and microscopic encrusters, a bio-mechanism not observed in mud mounds elsewhere. Fluctuating environmental conditions lead to the alternate dominance between the two groups, resulting in accretion and stabilisation of carbonate muds. These mounds are compositionally different to their Pennsylvanian counterparts.
\end{abstract}

Keywords Composite mound · Agglutinated microbial mound $\cdot$ Cluster mound $\cdot$ Donezella $\cdot$ Encrusting biota $\cdot$ Microfacies analysis $\cdot$ Pennsylvanian

\begin{abstract}
Resumen
Propósito Los montículos de la Formación San Emiliano de edad Pensilvaniense (Cantabrian Mountains, España) están comúnmente bien bexpuestos. Estos montículos tienen una altura de 2 a $50 \mathrm{~m}$ y se observa que son rasgos geológicos primarios. El los montículos se describen y clasifican y los factores y controles de la nucleación, el crecimiento y la fallecimiento tienen que ver con los siguientes factores se ha establecido.

Métodos El análisis de microfacias de 177 sección delgada ha revelado la composición de los montículos y carbonatos circundantes.

Resultados Montículos compuestos, que exhiben los componentes característicos de ambos montículos Cluster y Microbial aglutinado. Se describen los montículos. Los montículos son esqueléticos-microbianos lodogranular/lodosa. Peloide, homogéneo y coagulado micrites son los principales componentes sedimentológicos de los montículos. Los microfósiles dominan con Donezella, Claracrusta, Rothpletzella y Girvanella son comunes. Pequeños foraminíferos, briozoarios, corales y algas son todos ellos presente dentro de los montículos, pero son más comunes dentro de los carbonatos fuera del montículos.

Conclusiones La formación de los montículos estaba controlada por una relación dinámica entre las algas donezellaceanas, y incrustaciones microscópicas, un mecanismo biológico no observado en montículos de lodo en otras partes. Medio ambiente fluctuante condiciones conducen a la dominación alternada entre los dos grupos, resultando en la creación y estabilización de lodos de carbonato. Estos montículos son compositivamente diferentes a sus contrapartes de Pensilvaniense.
\end{abstract}

Palabras claves Montículo compuesto $\cdot$ Montículo microbiano aglutinado $\cdot$ Montículo de cúmulos $\cdot$ Donezella $\cdot$ Biota incrustante $\cdot$ Análisis de microfacias $\cdot$ Pensilvaniense

Extended author information available on the last page of the article 


\section{Introduction}

Carbonate mud mounds are a type of marine buildup which originate by the successive vertical and lateral accretion of carbonate muds (Monty 1995). This type of buildup became increasingly recognised during the 1970s and 1980s when it was found that various mound types, and their associated structures, microfacies and biotas extended a diverse geological range and often included features which were poorly understood or unknown at the time (Wilson 1975; James 1980; Longman 1981; James 1983; Lees 1988; Monty et al. 1988; Swennen 1988). Mud mounds are complex structures which respond to facies changes and have been found to record shifts in lithofacies and biofacies (Monty 1995).

A wide variety of reef and mound types, ranging from Waulsortian-type mounds, biodetrital and microbial mounds, stromatactoid mounds, Tepee Buttes and a variety of others, have been reported both temporally and spatially (e.g. Monty 1995; Pratt 1995; Kaufmann et al. 1996; Neuweiler et al. 2001; Krause et al. 2004; Hebbeln and Samankassou 2015). Riding (2002) reviewed the historical classification of organic reefs, in an attempt at the standardisation of what is a fraught nomenclature. The mounds described here are classified according to that standardisation. Individual populations of mounds are generally distinguished by their varying biological, sedimentological and tectonic settings, a distinction between Palaeozoic and Mesozoic mounds also exists (Schmidt et al. 2001). Due to the polygenetic nature of reefs and mud mounds, analysis of individual populations is fundamental to understanding the factors influencing their presence (e.g. Flajs et al. 1995). The nomenclature of Riding (2002) is based on reef structure. Presented here is a population of mounds from the Pennsylvanian aged San Emiliano Formation, Cantabrian Mountains, Spain. These mounds have a unique growth dynamic controlled by two competing ecological assemblages which has not yet been described. The mounds observed fall into the category, as defined by Riding (2002), of Cluster mounds, although small volumes of the mounds, dominated by encrusting biota are considered as Agglutinated Microbial mound components. Due to this overlap, the term 'Composite mound' is used to encapsulate the differing structures observed. The nucleation of, growth and subsequent demise of these San Emiliano Fm. mounds is also discussed.

Pennsylvanian 'carbonate mud mounds' from the Cantabrian Mountains have been described by Bowman (1979), Riding (1979) and Samankassou (2001) additionally, Hensen et al. (1995) described both primary and diagenetic mounds from the area.

\subsection{Geological setting}

The San Emiliano Formation is located within the Cantabrian Mountains (Fig. 1), León Province, Northern Spain, around the small rural town from which it takes its name. The area sits within the Iberian Massif, which itself has been informally arranged into six tectonostratigraphic units. These units were based upon differences in facies associations, structural styles, metamorphism and magmatism (Lotze 1945). The northern most of these units is where the study area is located and is called the Cantabrian zone (Lotze 1945; Pérez-Estaún et al. 1988). The Cantabrian zone consists of an incomplete Cambrian-Ordovician sedimentary sequence, a Silurian and Devonian sequence which is complete toward the west but is missing elsewhere and several thousand metres of strata spanning the Tournaisian to the Gzhelian Stages (Bahamonde et al. 2002). The Cantabrian zone (Lotze 1945; Pérez-Estaún et al. 1988) is further subdivided into five tectonic units: the Fold and Nappe, Central Asturian Coalfield, Ponga Nappe, Picos de Europa and Pisuerga-Carrión provinces. The San Emiliano Formation belongs to the La Sobia-Bodón/Aramo units of the Fold and Nappe Province (Pérez-Estaún et al. 1988; Bahamonde et al. 2002). The formation was deposited within the foredeep depozone of a Variscan foreland basin.

The San Emiliano Fm. (Figure 2) consists of at least $1800 \mathrm{~m}$ (Bowman 1982) of Pennsylvanian aged (Bashkirian to Moscovian), alternating deltaic clastics and shallow marine carbonates, with rare, thin coal bands (Bowman 1979). At the San Emiliano type locality (i.e. the San

Fig. 1 a A geological map showing the area of study. Samples were obtained from carbonate units within the San Emiliano Formation (i.e. the blue bands), coordinates are in UTM. Specific localities, where individual mounds were sampled, are indicated by white stars, with the mound imaged in B shown as a red star. The inset shows the location of the study area (indicated by asterisk symbol) in regards to the Spanish and Portuguese landmasses. (Modified after Suárez et al. 1991). Key in right-hand column bellow. UTM coordinates of the named villages (from west to east: Robledo de Babia-29T 738542.31 4761967.82; Cospedal-29T 740471.87 4762102.02; La Majúa-29T742542.18 4763067.04; San Emiliano-29T 744642.62 4762013.24; Candemuela-30T 255531.56 4763579.80; Villargusan-30T 2565587.05 4764801.92; Pinos-30T 257036.76 4763119.49. b Picture and annotated field sketch of a typical mound from the San Emiliano Formation, due to this mounds location at the side of a road, and the cut through of the mound provided, it is the most accessible outcrop that displays basal, mound, capping and offmound facies in the Valley (29T 744467.52 4763114.34). c A field sketch highlighting the geometrical relationships between mounds. The sketch is of $1 \mathrm{~km}$ of the carbonate unit that stretches continuously from just south of the village of Cospedal, to the village La Majúa. The sketch begins $500 \mathrm{~m}$ south-east of Cospedal (29T 741166.91 4761689.94) and encompasses the ridge, eastward toward La Majúa (29T 742631.65 4762673.57). The sketch was taken from the northern-most point of the carbonate ridge, approx. $200 \mathrm{~m}$ south of the mound bearing unit (29T 742640.14 4761171.31) 


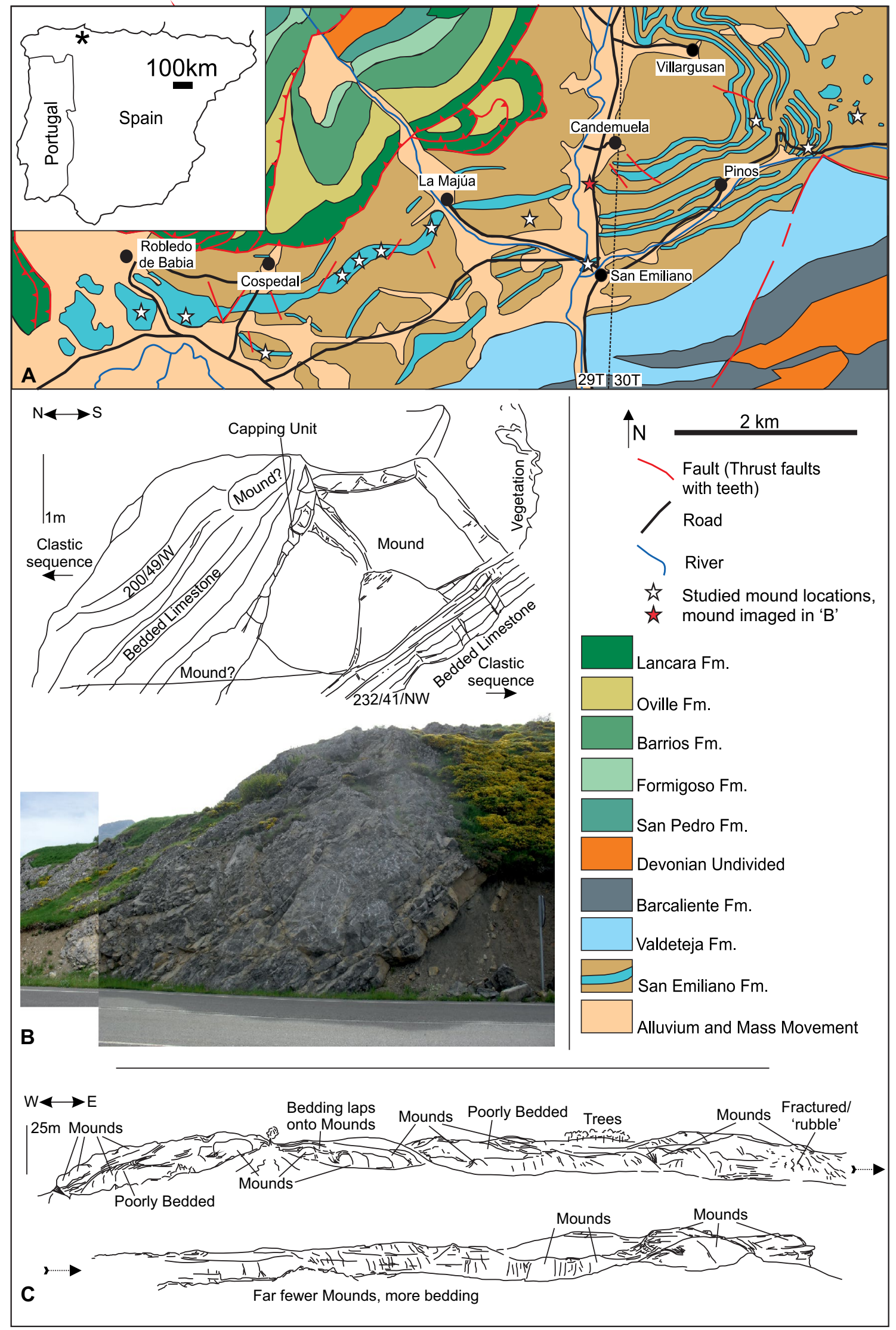




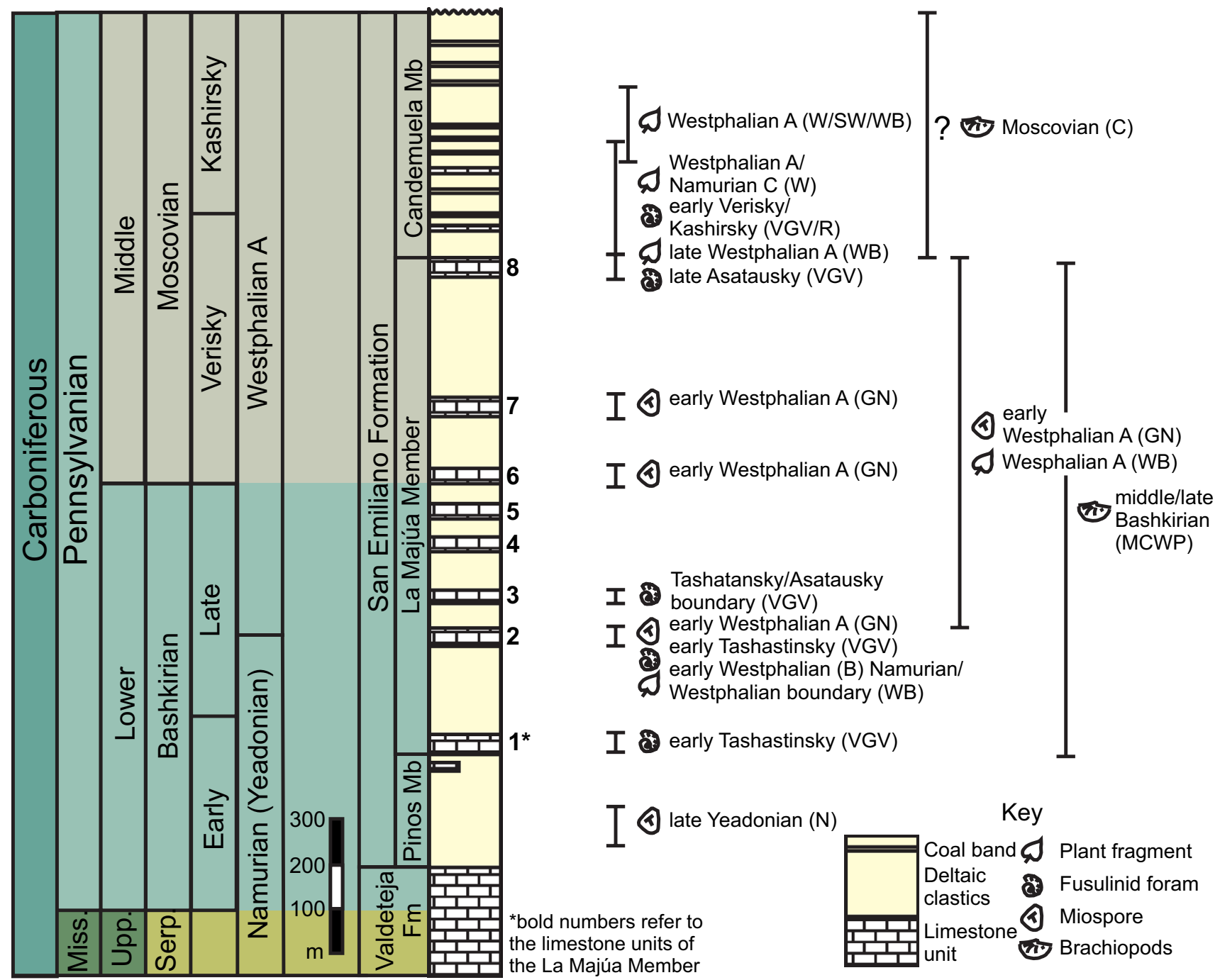

Fig. 2 Litho- and biostratigraphy of the San Emiliano Formation at the type point, San Emiliano. The age of the Formation is based upon various authors' stratigraphic studies, alluding to a Bashkirian to early Moscovian age for the La Majúa Member. Specimen bearing limestone units are labelled 1-8. B Bowman (1982); $C$ Carballeira et al. (1985); GN Gueinn and Neves in Bowman (1982); MCWP Mar-

Emiliano valley) Bowman (1982) subdivided the formation into three constituent members, based upon the proportions of clastic and carbonate sediments. These are the [1] Pinos, [2] La Majúa and [3] Candemuela Members. The [1] Pinos Member consists of black shales passing into siltstones with thin sandstone interbeds; the member is approximately $250 \mathrm{~m}$ thick. The [2] La Majúa Member consists of alternating regressive deltaic and shallow marine clastics (with some thin coal bands) separated by eight major limestone units (Bowman 1979); the member is approximately $1050 \mathrm{~m}$ in thickness. Fusulinid Foraminifera collected from the upper part of the La Majúa Member have indicated a late Bashkirian age (van Ginkel and Villa 1996). Mud mounds tínez Chacón and Winkler Prins (1979); N Neves in Bowman (1982); $R$ Rumjantseva in Wagner and Bowman (1983); $S W$ Stockmans and Williér (1965); $V G V$ Van Ginkel and Villa (1996); $W$ Wagner (1959); WB Wagner and Bowman (1983). Miss. Mississippian, Upp. Upper, Serp. Serpurkhovian, $\mathrm{Fm}$ formation, $\mathrm{Mb}$ member. Modified after Van Ginkel and Villa (1996)

(Fig. 1) are not observed within all eight of the limestone units of the La Majúa Member and seem to be confined to units 1, 4 and 8 (Fig. 2). Non-mound bearing units ranged from off-mound carbonates typical of the formation or 'Phylloid' algal bearing wackestones. The [3] Candemuela Member consists of deltaic and shallow marine clastics with coal beds and seatearths; the member is approximately $500 \mathrm{~m}$ thick.

Thirty kilometres east of the San Emiliano Valley, in the Bernesga Valley, a Moscovian aged succession, comprising mainly turbidites, carbonate debris flows and shallow water siltstones can be found exposed in the northern flank of the Cármenes syncline (Bowman 1982; van Ginkel and Villa 
1996). This sedimentary succession is commonly known as the Lois-Cigüera Formation (Rácz 1964; Brouwer and van Ginkel 1964; de Meijer 1971; Van De Graff, 1971; Bowman 1982, 1985), and is a stratigraphic equivalent to the San Emiliano Fm. The Lois-Cigüera Fm. consists of the basal Villanueva Beds, the middle "Caliza masiva" unit and the top Villamanín Beds. Brouwer and van Ginkel (1964) erected the Lois-Cigüera Fm. on the basis that the sediments were mostly detrital (tubiditic and debris flow). Moore et al. (1971) reported the San Emiliano Formation as missing or reduced along the northern limb of the Cármenes syncline, and reported that the "rhythmic units" of the San Emiliano Fm. (as observed in the vicinity of San Emiliano) are not found in the Villamanín area and are absent (or reduced) as a result of uplift and erosion, the responsible uplift believed to be associated with the Cantabrian Block (as defined by Radig 1962). Bowman (1982) reports several lithologies (turbidites, shallow water siltstones and carbonate debris) which are recognised as being the same age as the San Emiliano Fm. Due to the sufficiently distinct facies and distribution the Lois-Cigüera Fm. is separated from their San Emiliano valley counterparts (Bowman 1982; van Ginkel and Villa 1996). The San Emiliano Fm. was often mistakenly reported from the Villamanín area previous to Moore et al. (1971) and Bowman (1982). The distinction is still not recognised by some authors (Riding1979; Samankassou 2001).

Outcrops that were investigated and sampled for this study are along the well exposed limestone ridges of the La Majúa Mb. located within the San Emilliano Valley. 277 Samples were obtained from a total of 24 locations across the valley. The majority of samples were taken across the laterally extensive exposure of the uppermost carbonate unit of the La Majúa Member (unit 8, Fig. 2) of the San Emiliano Fm. (Figure 1c) in addition to detailed sampling at localities where mounds are well exposed and accessible (Fig. 1a). Sampling included coverage of the basal, mound, capping and off-mound facies, where possible. The results presented are based on a detailed microfacies analysis of 177 thin sections.

\section{Microfacies analysis}

Mound bearing units exhibit similar vertical profiles, consisting of approximately $30 \mathrm{~cm}$ to $3 \mathrm{~m}$ of bedded limestones (basal facies), followed by $2-50 \mathrm{~m}$ of carbonate mud mound/s (mound facies) lacking in primary geological features, which is in turn overlain by further bedded (up to $10 \mathrm{~m}$ ) limestones (capping facies). In places, a bed of 10-30 cm thick siliciclastic rich carbonate can be observed to onlap and drape over the mounds (see Fig. 1b for a typical example). The basal facies, mound facies and capping facies and the relationship between them are all considered here.
Carbonate units from the San Emiliano Fm. which are barren of carbonate mud mounds are also, briefly, considered.

\subsection{The basal facies}

The basal facies often consists of approximately $1 \mathrm{~m}$ of bedded limestones, individual beds range from 13 to $32 \mathrm{~cm}$ thick. In hand specimen the basal facies appears as a bluegrey colour. Numerous macro fossils are visible, with shelly fauna, rugose and auloporid corals and algae identified. The limestones are micritic and exhibit a porcelaneous fracture. The basal microfacies is a skeletal-microbial bafflestone consisting of intertwining (often bio-cemented) thickets of branching Donezella (with some Beresella) thalli, associated with birdseye, fenestral and some poorly developed primary cavity fabrics filled with sparite. Calcimicrobes found within some of the cavities occur as clumps of sheaths within a homogenous and peloidal micrite. The primary cavities appear to be part of an irregular, porous network within the Donezella thickets. Areas around the Donezella thickets are dominated by bodies of encrusting Claracrusta, Donezella, Girvanella and probably encrusting foraminifera (Fig. 3a). The encrusting appears non-selective and coats algae, foraminifera, Girvanella and mudchips. Cortoids (Fig. 3b) and cyanoliths are present within the samples particularly where mudchips have undergone encrustation. Donezella thalli are mostly well preserved can be observed as either: in situ as a three dimensional "shrub" like framework with abundant baffled micritic sediment and free floating microfossils (Fig. 3b), or as broken fragments, these fragments show little sign of wear. The micrite-walled calcimicrobe Girvanella is commonly well preserved as small tangled clumps within thin layers of microspar which acts as a biocement between algal thalli, a micritic envelope is present on most bioclasts (Fig. 3a, b). Other than the dominant Donezellaceans and associated encrusting calcimicrobes (Girvanella and Rothpletzella), Archaeolithophyllum, Petschoria, Komia (and Ungdarella), Beresellids, Tuberitinidae and rare, small foraminifera's (including Tetrataxis) and ostracods are found.

\subsection{The mound facies}

The Composite mounds of the San Emiliano Fm. are a union of mound structures: carbonate mud with in-place skeletal elements (Cluster mound component) with subordinate volumes of laminar sediment trapping and binding microbial elements (Agglutinated Microbial mound component). The sediments are best described as a skeletal-microbial pack-wackestone often associated with fenestral cavities (Fig. 3c, e) and occasional stromatactoid cavities (Fig. 3f). The mounds vary in size ranging from 2 to $50 \mathrm{~m}$ in thickness and are steep sided, lens to mound shaped. Mounds appear 

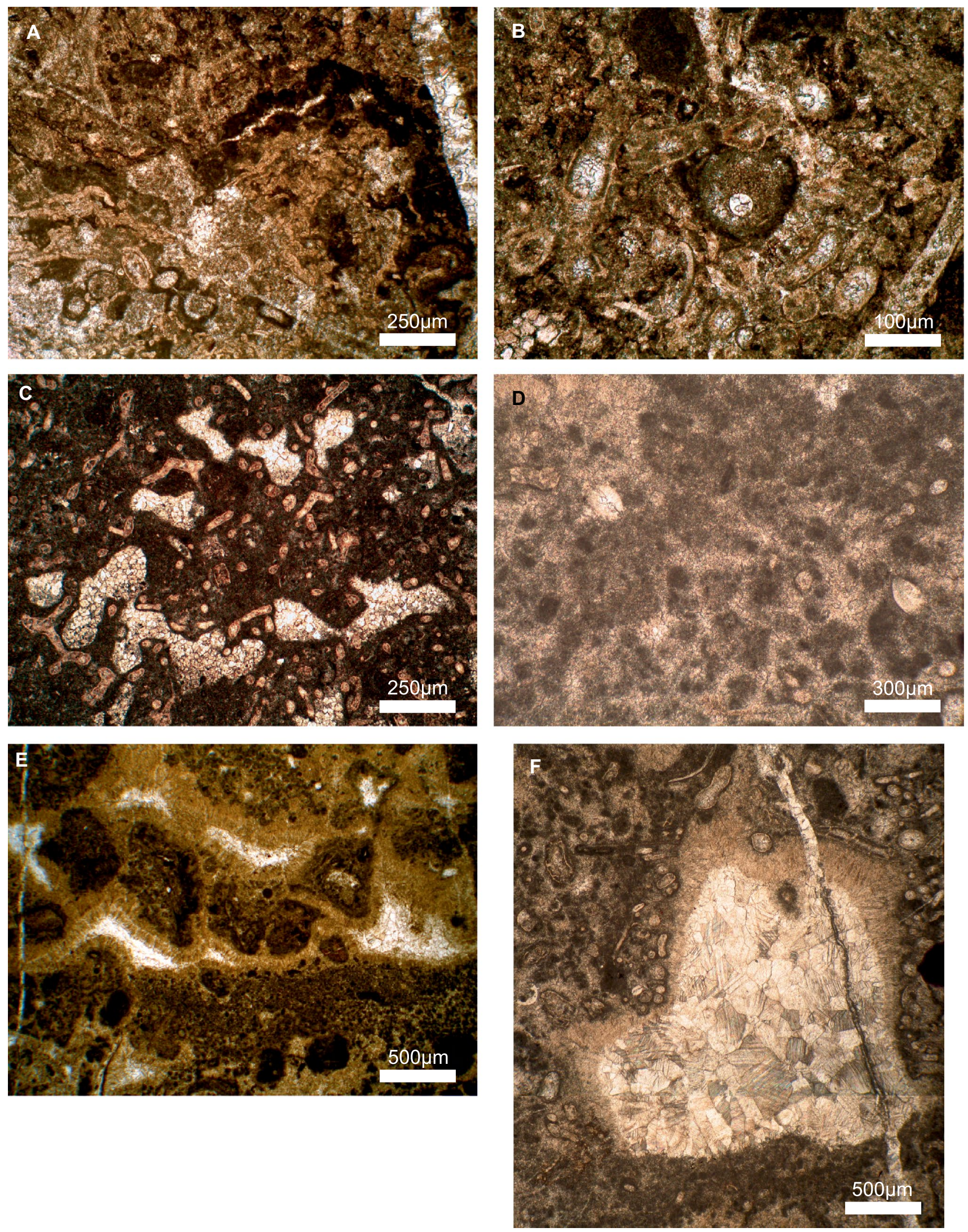
4Fig. 3 Photomicrographs of the basal and mound facies of carbonate mud mounds from the San Emiliano Formation. a Claracrusta specimens creating encrusting sheets of tubes which can be seen to branch, the sheets encrust several substrates showing no preference. The specimen exhibits the characteristic growth form of Claracrusta, the first few crusts are flat with few undulations, with subsequent crusts becoming increasingly convoluted. Encrusted substrates include: mud chips, Donezellacean thickets, Petschoria (a red ungdarellid algae) and Girvanella. b Entwined Donezellacean algae, several thalli are cemented together with clotted micrite and bio-cement. A cortoid (centre) exhibiting a characteristically uneven surface with microborings and encrusters. c Several fenestral cavities. Homogenous micrite is the dominant sediment with some peloidal and clotted micrite. The cavities have a sparitic fill with no evidence of a stromatactoid fabric. The geometry of the cavities (flat base, undulating roofs) in the bottom half of the figure may suggest some sort of hard ground or surface on which the base of the cavity network has formed, with the roof being defined by algal growth. d Sub-rounded micritic grains. Some areas consist of poorly sorted grains with distinct size differences. e Several examples of laminar stromatactis cavities, with characteristic flat bases, undulose roofs, internal sedimentary fill and both fibrous and blocky calcite cements. In this example the cavities are very closely spaced, with the top of one set of cavities forming the base of the next. f A stromatactoid cavity. This example of stromatactis appears surrounded by Donezellacean algae, many examples of cavity fabrics from this study show the same relationship, with the algae directly responsible for the construction of the cavity framework

as either isolated buildups or as superimposed complexes of two or more mounds (Fig. 1c). Individual mounds do not show any evidence of asymmetry, preferred orientation or thickness changes. Mounds are micritic and in hand specimen are lighter in colour than the basal and capping facies counterparts. Rare occurrences of siliciclastic conglomerates were observed within mounds (an accessible outcrop can be found at 29T 738867.33 461336.25) towards the west of the formation (near the village of Robledo de Babia.)

The mound facies is a fenestral packstones (Fig. 3c) characterised by non-laminated peloidal and clotted micrite (Fig. 3d) associated with variously sized fenestral cavities and bioclasts. Cavities are spar-filled and range from small 'birdseye' to larger, irregular voids (Fig. 3c, e). Several cavities have a stromatactoid fabric; flat based voids with undulating roofs, often with fine sediment fill at the bottom (Fig. 3f). Isolated clasts of sedimentary framework can be found within some of the larger cavities, as can a rare, sparse, coating of pyrite. The sedimentary framework consists of both sparitic and mictitic peloids, the latter associated with a relative abundance of encrusted Donezella (with some accessory Beresella and Dvinella) thalli, peloids are often thromboidal or aligned. Homogenous micrite occurs exhibiting no obvious fossil content and little in the way of sedimentary fabrics, in association with Donezellaceans (Fig. 3d). In places a clotted texture can be observed within the micrite (Fig. 3d-f). Several cyanolith like growths and encrusting sheets are observed; individual algae thalli are rarely encrusted, although in situ thickets or 'shrub-like' growths are (Fig. 3a). Encrusting sheets occur in a repetitive manor in association with alternating Donezellacean growths. Biodiversity observed within this facies is low; associated with the highly dominant Donezellaceans are rare Tuberitinidae and foraminifera, plus Komia, Archaeolithoporella and encrusting Claracrusta, Rothpletzella and others (Fig. 4a). Some selective dolomitisation has occurred, often as contact or floating equigranular rhombic to non-rhombic crystals within the blocky cement filling the fenestral cavities.

Microfacies investigation of the mounds revealed two sub-facies that occur in a repetitive pattern. The first sub-facies (sub-facies a) is a fenestral pack-wackestone characterised by non-laminated peloidal and clotted micrite and encrusted Donezellacean thalli (Fig. 3c, d). The sedimentary framework consists of both sparitic and micritic peloids and although they are non-laminated they are often thromboidal or ordered. Clotted micrite occurs in places, as does homogenous micrite, both are commonly found as cavity fill. Donezella (and accessory Beresella) are well preserved and relatively large, forming isolated and aligned thickets, sub-facies a forms the Cluster mound (Riding 2002) component of the mounds. The second sub-facies (sub-facies b) is characterised by encrusting calcimicrobes, namely, Rothpletzella and Claracrusta with occasional Girvanella and Wetheredella growths (Fig. 4a-c). These encrustations occur as laminar sheets of branching filaments; both tightly, and loosely packed growths with homogenous and peloidal micrite and some sparry cement between individual laminae occur. Rare foraminifera (mostly Tetrataxis, Lasiodiscus and very rare Bradyina) have been observed, often between entwined Donezella thali. Sub-facies b forms the Agglutinated Microbial mound (Riding 2002) component of the mounds. Sub-facies b is volumetrically less significant than sub-facies a, with encrusting sheets often being micron to millimetre in scale (Fig. $4 \mathrm{a}-\mathrm{c}$ ).

\subsection{The capping facies and off-mound facies}

The capping facies and off-mound facies (those carbonates flanking or occupying space between mound bearing strata) consist of bedded carbonates. The beds directly above the mounds often have a high clastic component, they are a dark grey in colour and are observed to drape over/onlap the mounds. The contact between the capping facies and the mound facies is sharp. Beds are thinner than those of the basal facies, ranging from 5 to $25 \mathrm{~cm}$ thick. The clastic-rich bed directly above the mounds are grain supported packstones consisting of broken and transported fossil fragments, sparry calcite crystals and an insoluble clastic/ organic material sedimentary framework (Fig. 4d). Calcite crystals occur interspersed within a poorly laminated very 

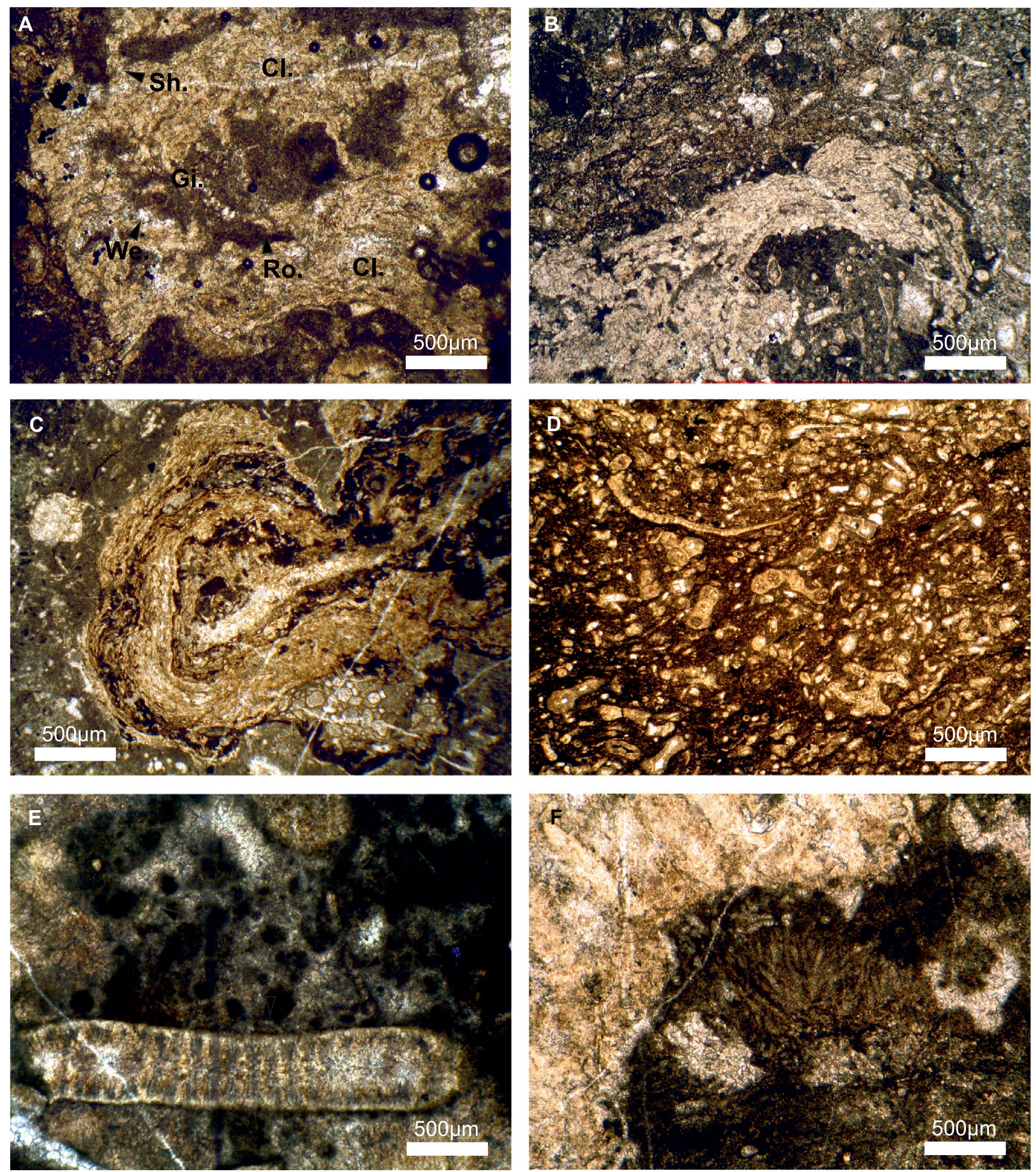

fine quartz and insoluble organic framework. Bioclasts are dominantly broken Donezellacean fragments, the orientation of which is slightly imbricated. Tuberitina are observed as well as some encrusting Komia and large fragments of bryozoan fronds. Several flattened, opaque lenses occur, these are possibly plant fragments which have been compacted by further sedimentation, shell fragments also appear slightly flattened. Above these beds the carbonates are classified between a wacke- and packstone. These are characterised by a homogenous to slightly peloidal micrite sedimentary framework, partially baffled by branching Donezellaceans and partly supporting large bioclasts (over $1 \mathrm{~mm}$ in size) and 
4Fig. 4 Photomicrographs of the mound facies, capping facies and selected biota of carbonate mud mounds from the San Emiliano Formation. a A community of microscopic encrusters consisting of Wetheredella (We.), Girvanella (Gi.), Rothpletzella (Ro.) and Shamovella (Sh.) in association with the dominant encruster, the algae incertae sedis, Claracrusta (Cl.). The dark micritic patches at the centre of the calcimicrobial dome exhibits some branching features and several components that most resemble micritized cyanobacterial/calcimicrobial tubes. b Rothpletzella encrusting a Donezella thicket. Note that successive rows of Rothpletzella are concordant with the previous row. c A calcimicrobial community encrusting a 'phylloid' algae thallus. The encrusters comprise of Rothpletzella, and Claracrusta. Some Archaeolithoporella which is characterised by couples of dark and light laminae is present as are globular, cystose growths which resemble Wetheredella (black arrow). d Broken algal thalli and other bioclasts forming a weakly laminated packstone. e Dvinella. Note the thin micritic envelope surrounding the bioclast and the peloids that appear to be stacked vertically from the flat, upper surface of the specimen. Several of the peloids appear thrombolitic or aligned in nature and resemble the calcified bacteria Renalcis. Faint, but discernible filaments can be observed attached to the Dvinella clast, these are possibly calcimicrobial sheaths. The evidence from this photomicrograph suggests that the clotted peloidal material may well be micritised remains of cyanobacterial colonies. f Girvanella

cortoids. Bioclasts are densely packed and consist mainly of Donezella and Beresella thalli. Donezella occurs as both a branching three dimensional network and as broken fragments. Some algal thalli are micritised with wall structures destroyed, leaving only outlines of the thalli. Bryozoans are relatively common in these samples and are often the largest bioclasts found. Bioclasts are frequently enveloped by a micritic rim. Foraminifera and calcimicrobes are well preserved and appear with relatively high biodiversity, both mobile and attached forms of Tuberitinidae are also well preserved and relatively abundant. A few rare echinoid plates are present. Calcimicrobial assemblages range from small isolated clumps, to larger encrustations involving several organisms. The cortoids in these samples are spherical in nature and resemble ooids but for the lack of any laminae, they generally consist of a recrystallized spherical nucleus with a micritic rim exhibiting calcimicrobial growth. These samples show a biodiversity higher than samples from the mound facies, the microfossils present within these samples are well preserved.

\subsection{Non-mound bearing units}

Several of the carbonate units of the La Majúa Mb. were observed to be barren of mud mounds. These units resembled either the basal facies or consist of bedded whole fossil wackestones and bioclastic packstones. The latter units appear as dark buff grey beds approximately $20 \mathrm{~cm}$ in thickness. Bedding is wavy in places and the limestones can often be observed to transition into marls toward the top of the beds. 'Phylloid' algae are common, found as laminar, to cyathiform and 'leaf'-like growths (e.g. the encrusted clast in Fig. 4c). Other macro-fossils include rugose and auloporid corals, brachiopods and gastropods. Archaeolithophyllum, Petschoria, Komia (and Ungdarella), Donezella and several types of encrusting calcimicrobe are present.

\section{Discussion}

The basal facies is characterised by well-preserved, dense thickets of Donezella and Beresella, which were common in Bashkirian and Moscovian age carbonates (see Sect. 3.1). These carbonates typically occur as low relief mounds or banks within marine lagoonal settings (Flügel 2004). Cortoids and cyanoliths suggest a shallow subtidal back-reef environment - in the geological setting of these sediments (i.e. a foreland basin) it is envisaged that a tectonic structure (e.g. a blind thrust or the forebulge) may act as a barrier in the place of a 'traditional' reef. The Barcaliente and Valdeteja Formations (which were deposited to the north and south of the San Emiliano Fm.) may also have acted as a barrier. Behind these, a lagoonal (or lagoon-like) environment is interpreted to have formed. The low-diversity of the microfacies would suggest a relatively stressed environment, the high number of algae and little else may suggest a brackish environment. Although rare, the occurrence of attached Tetrataxis is further evidence for a stressed environment (Cossey and Mundy 1990). The low diversity and simple nature of the taxa observed may indicate a pioneer community. The biological niche the organisms have filled is certainly newly opened-as evident in the shift in lithology (from clastic dominated to carbonate dominated). The disparity of microfacies evident between the basal and mounds facies indicates a change in environmental conditions or possibly ecological tiering, whereby the Donezella dominated mounds successfully establish themselves in the newly opened niche.

The light colour of the mounds (when compared to the darker basal, capping and off-mound beds) may indicate a lower Total Organic Content value, perhaps alluding to a shorter formation period. The shape of the mounds doesn't suggest any asymmetry. The boundary between mounds and onlapping (or draping) beds-may also indicate that the mound accumulated faster than the surrounding capping and basal facies. The mound facies is dominated by various packstones, containing mostly Donezellaceans. Peloidal micrite and homogenous micrite are more common than in the basal beds, and in some cases are the major constituents. Much of the peloidal micrite is nonlaminated and appears as clotted growths and other "shrub" like forms. The presence of what are quite possibly calcified filamentous cyanobacterial sheaths suggests that peloids are possibly micritised remains of these and of the calcareous algae. Homogenous 
micrite is often in association with faint thrombolytic textures, perhaps hinting at a microbial or algal origin. The heterolithic nature of the mound facies possibly indicates a considerable variation in current flow, energy conditions, sea levels and/or nutrient levels during the deposition of the mud mounds. The biota associated with this facies remains mostly the same as the basal assemblage and is dominated by non-complex alga and encrusting cyanobacterial forms. This association of biota suggest a restricted, shallow, low energy environment. Evidence for changing conditions is present along with some higher energy events, although the environment is interpreted to remain dominantly restricted, shallow and low energy throughout the deposition of the mounds. The capping facies consists of three distinct lithologies: a packstone characterised by its lithoclastic component in addition to its bioclastic component which is found 'draped' over several of the mounds. Above that is a wackepackstone with accessory bioclasts which include taxa typical of metazoan dominated carbonates. The relatively large, reworked and broken bioclasts within the unit draped over the mounds, plus the presence of increased clastics indicate a higher energy depositional environment than that of the mounds. Some imbrication of bioclasts and lamination is evident, suggesting stronger current activity. The occurrence of several different foraminifera, bryozoans and more Tuberitina may indicate the environment is becoming less restricted. Donezellaceans are absent or found as broken and transported clasts within most of the capping facies. However, the occurrence of a similar biological community, and the presence of mud chips, it is envisaged that the depositional depth of the last unit was similar to the depth of mound formation or slightly deeper, but with a higher energy level. The higher energy may be a result of the environment becoming more open, making it difficult for the algae to establish and grow into shrub like thickets. The mounds are thought to have been smothered by the draping (capping) units as a result of an increase of clastic material to the basin, probably as a result of thrust propagation (causing the migration of the foreland basin and increased clastic supply.) The bedded units on top of the mounds indicate a relative sea-level rise; this is interpreted to be flexure related basin subsidence. The changes in microfacies throughout the mounds suggest a steady sea level rise throughout deposition.

The presence of stromatactoid and fenestral cavities with internal early marine cement implies that there was constant movement of water through the carbonates when they were partially lithified, which would suggest the presence of a current or wave activity. The peloids, bioclasts, microfossils and cavities show little sign of compression, which may indicate an early lithification.

\subsection{Palaeoecology of the mounds}

The mounds have a distinct biological community consisting of Donezella (Fig. 3b, c) and several encrusting forms including: Rothpletzella, Claracrusta, Girvanella and occasionally Wetheredella and Shamovella (Fig. 4a). In some examples Girvanella (Fig. 4e) can be observed between entwined Donezella thalli. In other cases, Rothpletzella and Claracrusta can be found to encrust, bind and assumedly stabilise Donezella thickets. Evidence of calcimicrobial sheaths encrusting Donezellaceans is present (Fig. 4f). Donezella, Claracrusta and Rothpletzella are described in some detail before considering the biological assemblage as a whole.

Donezella is observed as either whole, bush- or shrublike growths often up to several centimetres in diameter, as sheet like encrustations of entwined thalli which appear to encrust the subjacent surface or as broken thalli which have been reworked. There are two common species observed; the type species, Donezella lutugini Maslov and Donezella lunaensis Rácz. Thalli are found to range from 50 to $275 \mu \mathrm{m}$ in diameter with an average diameter of $140 \mu \mathrm{m}$. Donezella is generally observed within the mound and basal facies of the observed mounds. Where Donezella is found in situ (as either a shrub like growth or as an encrusting sheet) it is always the dominant biota with very few other biotas found in association. Maslov (1929) originally assigned Donezella to the red algae (Johnson 1963), however, in successive subsequent studies Donezella has been considered to be: green (Codiaceae) alga (Rácz 1964), alga incertae sedis (Rich 1967), Foraminifera (Riding 1979), calcareous sponges (Termier et al. 1977), microproblematica (Riding 1979; Chuvashov and Riding 1984), green (Paleosiphonocladales) algae (Shuysky 1985; Ivanova 1999), green algae of incertae familiae (Groves, 1986), green (Dasycladales) algae (Deloffre, 1988) and pseudo-algae (Vachard et al. 1989). Recent work regarding Donezella refers to the genus as green (Chlorophycophyta) algae (Mamet and Villa 2004), algae incertae sedis (Mamet and Zhu 2005), algospongia (Vachard and Cózar 2010) or more commonly, microproblematica (Samankassou 2001; Della Porta et al. 2002; Choh and Kirkland 2006; Corrochano et al. 2012). Donezella accumulations are often interpreted to have grown within a warm, shallow (low to moderate energy, below fair-weather wave base) environment but have been shown to thrive over a range of water depths up to $200 \mathrm{~m}$ (Della Porta et al. 2002; Choh and Kirkland 2006; Corrochano et al. 2012). Environmental conditions from quiet to quite agitated have been interpreted (Rácz 1964; Bowman 1979). Donezella growths have been found to form in a range of environments ranging from platform interiors to deep-slopes (Della Porta et al. 2002). This cosmopolitan habit and ability of Donezella to occupy a variety of environments, quickly establishing itself 
and growing to maturity suggest that Donezella may be an example of the "opportunist" species of Connell and Slatyer (1977). The dominant occurrence of Donezella in the studied samples indicates that it played a direct role in the formation of the carbonates of the San Emiliano Formation, it is observed to both baffle and bind (in association with several encrusting organisms, specifically Claracrusta, Rothpletzella and Girvanella) and at a millimetre scale may be considered to be a constructor (Fig. 3c). In association with microscopic encrusters, Donezella was a successful baffler, binder and constructor, in regards to mound formation, Donezella must be considered as an integral component and directly linked to the nucleation, growth and success of carbonate mud mound formation within the San Emiliano Fm. Beresella and Dvinella are both found in association with Donezella, although they are rare. This important skeletal element of the mounds leads to the classification of this mound component to be that of a Cluster mound (Riding 2002).

Specimens of Claracrusta (Fig. 3a) are observed as laminar rows of irregular, often bean and ovoid to subquadratic shaped cells which have a honey or yellow coloured calcite wall. The cells have been referred to as tubular (Cózar 2005, and elsewhere), but here, appear to be ovoid or subquadratic, agreeing with Mamet and Villa (2004). Individual cells have been observed to range from 10 to $110 \mu \mathrm{m}$ but the average cell size is around $50 \mu \mathrm{m}$. Encrustations have the characteristic growth form of a concordant first lamination with subsequent encrusting laminations becoming more and more undulating; the space between laminations is generally filled with homogenous micrite or more rarely, other encrusting forms. Claracrusta appears to be non-selective in what it encrusts, although Donezella and Archaeolithophyllum appear to be the most commonly encrusted objects. Several examples of entire Donezella florets being encrusted have been observed and the preservation level is usually particularly high for these Donezella specimens (Fig. 3a). These florets are generally associated with homogenous micrite and constructed cavities which have been selectively dolomitised. Claracrusta in association with Rothpletzella, Girvanella and to a lesser extent Wetheredella (Fig. 4a), are considered to be important binders and stabilisers of Donezella growths and therefore the role they play within the formation of carbonate mounds within the San Emiliano Formation (particularly within the San Emiliano Valley) is very important.

Rothpletzella (Fig. 4a) is characterised by laminar sheet-like growths of branching tubes which lie parallel to the substrate. In transverse sections Rothpletzella often resembles a chain or bead like structure with individual filaments ovoid in shape, often resembling beans or sausages. Individual filaments have been reported to range from 13 to $37 \mu \mathrm{m}$ (Adachi et al. 2007) in diameter. Longitudinal cuts reveal dichotomous branching of filaments.
Filaments branch often and can form fan like structures. Filaments have a thin micritic wall and are filled with clear sparry cement. Rothpletzella grows as thin crusts and oncoids (Feng et al. 2010) and platy growths (Wood 2000). Growths are laminar and undulate to mimic the subjacent micro-topography (Fig. 4b).

Rothpletzella, Wetheredella and Girvanella in combination have been known to grow together symbiotically (Wood 1948) forming what is essentially a microbial organism where boundaries between the various components are impossible to see with the naked eye/optical microscope. This microbial organism was mistakenly interpreted as a single fossil and named Sphaerocodium (Wood 1948; Adachi et al. 2007). Rothpletzella is a commonly observed calcimicrobe in this study and is often found as well preserved laminations of juxtaposed ovoid filaments. The genus is often found in association with other encrusting alga and calcimicrobes, especially Claracrusta and Girvanella and more rarely Wetheradella. These calcimicrobes often form variously layered growths. Several examples have a microsparitic wall and are filled with micrite with the filaments measuring up to $50 \mu \mathrm{m}$ in height (width was not measured as it is unsure if the cutting angle is completely perpendicular to the filament). Several of the laminar growths of Rothpletzella reach up to a millimetre in height. The genus is usually found encrusting various bioclasts, in particular Donezella thickets (Fig. 4b) and 'phylloid' algae (Fig. 4c). This association of encrusting forms is interpreted to play an important role in the binding and stabilisation of Donezella thickets within the San Emiliano Fm. mounds, although minimal in volume, these micron to millimetre build-ups play a vital role, and are considered as Agglutinated Microbial mound (Riding 2002) elements. Both of the biological assemblage's present form build-ups of sediment with unique characteristics. These are individually interpreted as a Cluster mound element and an Agglutinated Microbial mound element. The introduction, and use of the term, 'Composite mound' to encapsulate this overlapping of mound structure allows for the appreciation of both of these important structural features of the mounds, without giving gratuitous emphasis to the volumetrically dominant element (i.e. in this case, the Cluster mound element).

The association of biotas presumably formed wave resistant, topographic mounds. The presence of bound and stabilised Donezella/encruster assemblages may have encouraged consecutive colonisation of the same area by subsequent Donezella and encrusters by acting as a substrate (Fig. 4b, 5). Other biota observed consist of low diversity assemblages and often consist of biota which may represent organisms living in a stressed environment (e.g. attached Tetrataxis). The concentration of Donezella and its ally taxa may have directly contributed to the low biological diversity; low diversity assemblages characterised by dominant 


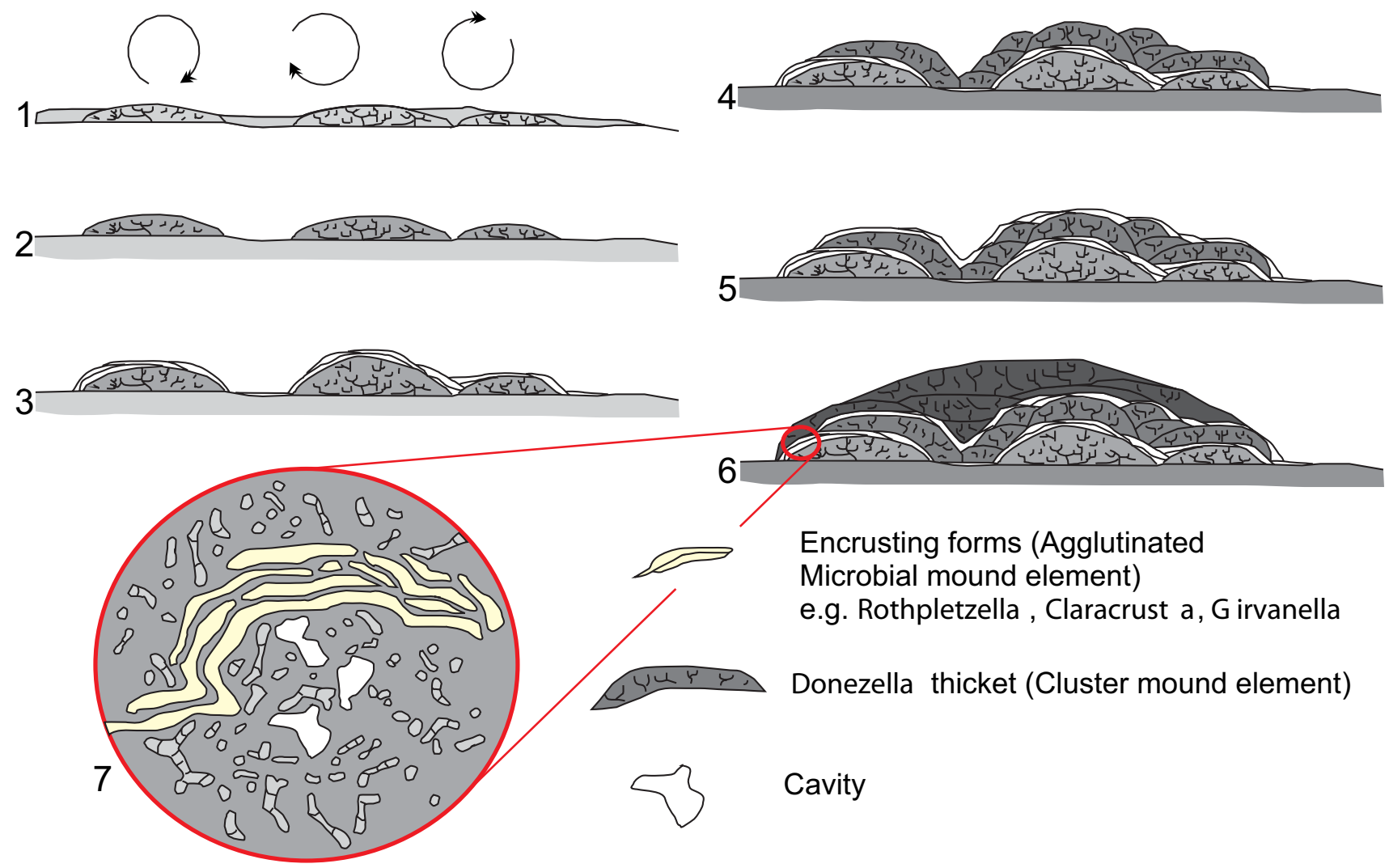

Fig. 5 A schematic representation of mound formation. (1) Donezella grows and is broken and abraded by local wave action and currents. (2) Donezella grows on top of the accumulated, broken Donezella. (3) Environmental conditions deteriorate and laminar encrusters colonise the substrate provided by the Donezella thickets. (4, 5 and 6 ) Environmental conditions continue to fluctuate resulting in the repetition of Donezella growth, and stabilisation by encrusting forms. (7) A close up of the area circled in (6), schematic representation of the

algal communities have been attributed to the exclusion of other biota from the living space via both chemical defence (poisons produced by the algae) and through the occupation of all available living space (Toomey 1976, 1991; Forsythe et al. 2002; Samankassou and West 2003; Enpu et al. 2007). Petschoria, Archaeolithophyllum, Komia and Ungdarella were all observed to be present within the mound facies, in far lesser numbers than the dominant biotas described above. There appears to be a reduced population or complete lack of grazers within environments where they would normally be expected. Bryozoans, corals and other biota often associated with Pennsylvanian aged carbonate deposits are generally restricted to the mixed clastic and bedded carbonate lithologies and are rarely seen within mounds within the San Emiliano Valley. Dasyclad algae, foraminifera, bryozoans, corals and other shelly fauna are more common within the Bernesga Valley mounds (Samankassou 2001). Thartharella and calcisponges, which were reported as a main component interaction of Donezella growths and laminar encrusters. Note that it is not individual Donezella thalli that are encrusted, but the 'shrub' like growths as a whole. The approximate scales for the individual components differ, Cluster mound elements range from millimetre to centimetre in vertical profile, Agglutinated Microbe mound components are often micron to millimetre in vertical profile. The area shown in 7 is approx. $2 \mathrm{~mm}$ across

of mounds from the Bernesga Valley (Samankassou 2001) are absent, or greatly reduced, from the San Emiliano Valley.

Several, distinct palaeoecological assemblages are recognisable from the studied material. Mound and off-mound carbonates (i.e. those carbonates found within the same unit as mounds) exhibit similar biological communities, however, distinct variations were observed between the abundance of certain biota between the communities. Bedded lithologies are associated with a palaeoecological assemblage distinct to those from mound bearing strata.

\subsection{Initiation, growth and demise of the mounds}

The Composite mounds from the type locality of the San Emiliano Fm. initiated as the result of several interacting factors. The combination of a newly opened niche within a restricted, warm and shallow basin encouraged the growth of pioneer or opportunist organisms. The absence of detrital clastic input allowed for carbonate producers to fully 
Table 1 Summary of documented occurrences of Donezella related buildups

\begin{tabular}{|c|c|c|c|}
\hline Mound description & Age & Location & References \\
\hline Low-energy buildups & Lower Permian & Central Texas (USA) & Wiggins (1986) \\
\hline $\begin{array}{l}\text { Donezella mounds with siliceous sponges, } \\
\text { Archaeolithophyllum and worm tubes }\end{array}$ & Lower Permian & Ouachita Mountains (Oklahoma, USA) & Choh and Kirkland (2000) \\
\hline $\begin{array}{l}\text { Donezella-Siliceous sponge dominated } \\
\text { carbonate buildup with worm tubes }\end{array}$ & Lower Pennsylvanian & Ouachita Mountains (Oklahoma, USA) & Choh and Kirkland (2006) \\
\hline $\begin{array}{l}\text { Donezella low bank to mound controlled } \\
\text { by water depth and energy }\end{array}$ & Moscovian & $\begin{array}{l}\text { Hueco Mountains (W Texas and SE New } \\
\text { Mexico) }\end{array}$ & $\begin{array}{l}\text { Lambert (1986) and Lambert } \\
\text { and Stanton (1988) }\end{array}$ \\
\hline $\begin{array}{l}\text { Skeletal microbial Donezella-Tubiphytes } \\
\text { (= Shamovella) biostromes }\end{array}$ & Bashkirian & California (USA) & Watkins (1999) \\
\hline $\begin{array}{l}\text { Donezella baffled mounds associated with } \\
\text { Petschoria, Komia and Archaeolitho- } \\
\text { phyllum }\end{array}$ & Bashkirian-Moscovian & Cantabrian Mountains (Spain) & Rácz (1964) \\
\hline $\begin{array}{l}\text { Donezella mounds with Komia, Ungda- } \\
\text { rella, encrusting foraminifers, 'phylloid } \\
\text { algae' and dasyclads }\end{array}$ & Bashkirian-Moscovian & Cantabrian Mountains (Spain) & Bowman (1979) \\
\hline Mounds sparse of Donezella (5-10\%). & Bashkirian-Moscovian & Cantabrian Mountains (Spain) & Riding (1979) \\
\hline $\begin{array}{l}\text { Donezella mounds with Petschoria, } \\
\text { Komia, Ungdarella, encrusting foramini- } \\
\text { fers, Archaeolithophyllum and bryozoans }\end{array}$ & Bashkirian-Moscovian & Cantabrian Mountains (Spain) & Eichmüller (1985) \\
\hline $\begin{array}{l}\text { Skeletal-microbial boundstone. Don- } \\
\text { ezella, agglutinated worm tubes and } \\
\text { calcisponges }\end{array}$ & Bashkirian-Moscovian & Cantabrian Mountains (Spain) & Samankassou (2001) \\
\hline $\begin{array}{l}\text { Skeletal microbial Donezella-Tubiphytes } \\
\quad(=\text { Shamovella }) \text { mounds }\end{array}$ & Bashkirian-Moscovian & Cantabrian Mountains (Spain) & Samankassou (2001) \\
\hline $\begin{array}{l}\text { Clotted microbial peloids with Donezella } \\
\text { and 'phyloid algae' }\end{array}$ & Pennsylvanian & Cantabrian Mountains (Spain) & Samankassou et al. (2013) \\
\hline $\begin{array}{l}\text { Donezella pack- wackestones mounds with } \\
\text { Rothpletzella and Claracrusta (Compos- } \\
\text { ite mound) }\end{array}$ & Bashkirian-Moscovian & Cantabrian Mountains (Spain) & This study \\
\hline $\begin{array}{l}\text { Donezella mounds with Beresella, } \\
\text { Komia/Ungdarella, bryozoans, crinoids, } \\
\text { encrusting foraminifers and ostracods }\end{array}$ & $\begin{array}{l}\text { Late Surpukhovian to } \\
\text { early Bashkirian }\end{array}$ & $\begin{array}{l}\text { Ellesmere Island (Canadian Arctic Archi- } \\
\text { pelago) }\end{array}$ & Davies and Nassichuk (1989) \\
\hline $\begin{array}{l}\text { Skeletal Donezella-Tubiphytes (= Sham- } \\
\text { ovella) mounds }\end{array}$ & Carboniferous & Kazakhstan & Cook et al. (2007) \\
\hline Donezella and Ungdarella buildups & Bashkirian & Western Urals (Russia) & Proust et al. (1996) \\
\hline
\end{tabular}

Mounds, bioherms and biostromes are all included in this table. It should be noted that Riding (1979) concluded that Donezella was not responsible for the formation of the studied mounds. Mounds are grouped into geographical locations

establish themselves, resulting in an 'in house' production of carbonate mud. Growth of the mounds resulted from the interaction of the genus Donezella and several encrusting forms including the genera Rothpletzella and Claracrusta. Fluctuating environmental conditions allowed the encrusting forms to bind and stabilise the framework building and carbonate mud baffling Donezella growths. Donezella grew during 'normal' environmental conditions within the basin whilst the encrusters, which were direct competitors for the environmental niche, flourished during deteriorating conditions (Fig. 5). Adachi et al. (2007) observed a similar relationship between Graticula-like red algae, Rothpletzella and laminar stromatoporoids in Lower Devonian age bindstones. The resulting stabilised (and likely wave/current resistant), encrusted Donezella thickets provided a substrate for further
Donezella growth when environmental conditions became more tolerable. The mounds ceased to form when detrital sediment deposition returned to the basin. Microfacies analysis indicated that when detrital input increased the environment became less restricted with encrusting forms becoming less common whilst (relatively) large and mobile metazoans become more common. The Donezella/encruster relationship ceased and mounds could no longer form. The major factors responsible for mound formation can be attributed to: a] biological community present, $b$ ] a restricted basin and c] a lack of clastic input. 


\subsection{Comparison to other mounds}

Throughout the Pennsylvanian Series, carbonate units associated with a dominance of Donezella growths are relatively common. Several examples also exist from the Permian, although these are far less abundant. These carbonates have been reported to form a wide variety of geometries and features including mud mounds (of various classifications), bioherms, biostromes and as carbonate ramps and platforms (Della Porta et al. 2002; Choh and Kirkland 2006 and references within). Other mounds (including bioherms and biostromes) containing Donezella are summarised in Table 1 and are loosely grouped into geographical location. Several common biological associations are apparent. An association with Petschoria, Archaeolithophyllum, Komia and Ungdarella is plain to see within the majority of these mounds. Several of the mounds, including those from the Bernesga Valley, are associated with worm tubes and siliceous sponges. No other mounds (other than those in this study), bioherms or biostromes have a reported biological association between Donezella, Claracrusta, Rothpletzella, Girvanella and other microscopic encrusting forms. The Composite mounds of the San Emiliano Valley have compositional and formational mechanisms that are unique when compared to other mounds with a dominant Donezella component, as well as other known populations of mounds from the Carboniferous. The depth and/or environmental setting at which the San Emiliano mounds formed may be the cause for this unique biological assemblage, most other Donezella mounds have been interpreted to form at a greater depth below sea level.

\section{Conclusions}

Three distinctive microfacies are recognised between the basal, mound and capping material of the carbonate units of the San Emiliano Fm. at its type point, plus an addition a fourth facies; carbonate units which are barren of mounds. Composite mounds from the San Emiliano Fm. are interpreted as skeletal-microbial pack-wackestones with various types of cavity networks. The dominant palaeontological communities were low diversity assemblages representing a pioneer or opportunist community living in a newly opened (relatively restricted) niche.

The dominant mound communities were: a Donezella community, with rare foraminifera (Tetrataxis and Lasiodiscus) (forming a Cluster mound component) and a laminar encrusting community comprising mostly of the genera Rothpletzella, Claracrusta and Girvanella (forming an Agglutinated Microbial mound component). These two communities competed for habitat and had a dynamic relationship controlled by fluctuating environmental conditions. Off mound sediments (basal and capping facies) were commonly associated with higher biodiversity, including biota such as bryozoans, corals and foraminifera. Sedimentary deposition of the mounds was characterised by autochthonous micrite, in the "in-house" manner, typical of many microbial mounds. The process identified as being responsible for the nucleation and growth of the mounds is a dynamic relationship between the Donezella dominated community and the laminar encrusting form dominated community. As indicated by microfacies analysis the environmental conditions of deposition fluctuated. Where conditions were near 'normal', Donezella flourished, acting as a microscopic framework builder as well as a baffler. Environmental 'degradation' led to the encruster guild becoming dominant. Laminar encrusters grew in a non-selective manner covering the majority of grain types. Commonly the encrusters could be found atop of Donezella thickets, stabilising and protecting the (supposedly) delicate Donezella thalli. When environmental conditions returned to suit Donezella the laminar encrusters provide a suitable substrate for new growth. The Composite mounds ceased to form due to drowning by a deepening sea-level or by an increase in clastic sediment resulting in a clastic-rich bed draped over the mound. The mechanism responsible for mud mound production within the San Emiliano Fm. is unique for known Donezella dominated mounds, and comparable Carboniferous mounds in general. The term Composite mound is used here to describe mounds bearing two or more of the structural characteristics defined by Riding (2002).

Acknowledgements The author would like to express his gratitude to the technical staff in GGE at Keele University for the preparation of all thin sections used. This study forms part of a $\mathrm{PhD}$ completed in 2015 at the University of Keele under the supervision of Dr Michael Montenari. The author is grateful to Sergio Rodriguez for providing constructive comments which greatly improved the manuscript. Javier Martín-Chivelet is thanked for his editorial assistance when this manuscript became a ghost in the system. Alex Nobajas is thanked for his assistance with the Spanish translation of the abstract.

Open Access This article is distributed under the terms of the Creative Commons Attribution 4.0 International License (http://creativeco mmons.org/licenses/by/4.0/), which permits unrestricted use, distribution, and reproduction in any medium, provided you give appropriate credit to the original author(s) and the source, provide a link to the Creative Commons license, and indicate if changes were made.

\section{References}

Adachi, N., Ezaki, Y., \& Pickett, J. W. (2007). Interrelations between framework-building and encrusting skeletal organisms and microbes: more-refined growth history of Lower Devonian bindstones. Sedimentology, 54, 89-105. 
Bahamonde, J. R., Colmenaro, J. R., Fernández, L. P., Moreno, C., Barba, P., Heredia, M., et al. (2002). Carboniferous. In W. Gibbons \& M. T. Moreno (Eds.), The geology of Spain (pp. 93-116). London: Geological Society.

Bowman, M. B. J. (1979). The depositional environments of a limestone unit from the San Emiliano Formation (Namurian/Westphalian), Cantabrian Mts., NW Spain. Sedimentary Geology, 24, $25-43$.

Bowman, M. B. J. (1982). The Stratigraphy of the San Emiliano Formation and its relationship to other Namurian/Westphalian A sequences in the Cantabrian Mts., N W Spain. Trabajos de Geologia, 12, 23-35.

Bowman, M. B. J. (1985). The sedimentology and paleogeographic setting of late Namurian-Westfalian. A basin-fill succession in the San Emiliano and Cármenes areas of NW León, Cantabrian Mountains, NW Spain. In: Lemos de Sousa, H. J. \& Wagner, R. $\mathrm{H}$. (eds), Papers on the Carboniferous of the Iberian Penninsula (Sedimentology, Stratigraphy, Paleontology, Tectonics and Geochemistry), Annales da Faculdade de Ciências, Universidade do Porto, Special Supplement to Vol. 64, 117-168.

Brouwer, A. \& van Ginkel, A. C. (1964). La succession Carbonifére dans la partie méridionales des montagnes Cantabriques (Espagne Nord-Ouest). CR, 5éme Congrés sur la Carbonifére, Paris, 1, 307-319.

Carballeira, J., Corrales, I., Valladares, I., Naval, A., Ruiz, F., Lorenzo. S., Martínez Chacón, M. L., Mendez, C., Sanchez De Posada, L. C. \& Truyols, J. (1985). Aportaciones al conocimiento de la estratigrafía de la Formación San Emiliano (Carbonífero, Cordillera Cantábrica) en su area-tipo. Compte Rendu 10ème Congrès sur le Carbonifere, Madrid, 1983, 1, 345-362.

Choh, S-J. \& Kirkland, B. L. (2000). Microfacies, biota, and depositional environment of an early Pennsylvanian (Morrowan) Donezella-siliceous sponge dominated bioherm, Frontal Ouachita Thrust Belt, Oklahoma, USA (abstract). SEPM-IAS Research Conference on Permo-Carboniferous Platforms and Reefs. El Paso, Texas, 15-16 May 2000, 37

Choh, S.-J., \& Kirkland, B. L. (2006). Sedimentological role of microproblematica Donezella in a Lower Pennsylvanian Donezella-siliceous sponge-dominated carbonate buildup, frontal Ouachita thrust belt, Oklahoma, U.S.A. Journal of Sedimentary Research, 76, 152-161.

Chuvashov, B., \& Riding, R. (1984). Principal floras of Palaeozoic marine calcareous algae. Palaeontology, 27, 487-500.

Connell, J. H., \& Slatyer, R. O. (1977). Mechanisms of succession in natural communities and their role in community stability and organization. The American Naturalist, 111, 1119-1144.

Cook, H. E., Zhemchuzhnikov, V. G., Zempolich, W. G., Lehmann, P. J., Alexeiev, D. V. Ya. Zhaimina, V. \& Ye. Zorin, A. (2007). Devonian and Carboniferous Carbonate Platform Facies in the Bolshoi Karatau, Southern Kazakhstan: Outcrop Analogs for Coeval Carbonate Oil and Gas Fields in the North Caspian Basin. In: Yilmaz, P.O. \& Isaken, G.H. (eds), Oil and Gas of the Greater Caspian Area:, American Association of Petroleum Geology Studies in Geology, No. 5, 159-163.

Corrochano, D., Barba, P., \& Comenero, J. R. (2012). Transgressiveregressive sequence stratigraphy of Pennsylvanian Donezella bioherms in a foreland basin (Lena Group, Cantabrian Zone, NW Spain). Facies, 58, 457-476.

Cossey, P. J., \& Mundy, D. J. C. (1990). Tetrataxis: a loosely attached limpet-like foraminifera from the Upper Palaeozoic. Lethia, 23, 311-322.

Cózar, P. (2005). Early Serpukhovian (late Mississippian) microflora from the Guadiato Area (southwestern Spain). Geological Journal, 40, 405-424.

Davies, G. R. \& Nassichuk, W. W. (1989). Upper Carboniferous tubular algal boundstone reefs in the Otto Fiord Formation, Canadian Arctic Archipelago. In: Geldsetzer, H. H. J., James, N. P. \& Tebbutt,
G.E. (eds), Reefs, Canada and Adjacent Area, Bulletin of Canadian Petroleum Geology. 13, 649-657.

de Meijer, J. J. (1971). Carbonate petrology of algal limestones (LoisCiguera Formation, Upper Carboniferous, Leon, Spain). Leidse Geologische Mededelingen, 47, 1-53.

Della Porta, G., Kenter, J. A. M., \& Bahamonde, J. R. (2002). Microfacies and paleoenvironment of Donezella accumulations across an Upper Carboniferous high-rising carbonate platform (Asturias, NW Spain). Facies, 46, 149-168.

Deloffre, R. (1988). Nouvelle taxonomic des algues dasycladales. Bulletin des Centres de Recherches Exploration-Production ElfAquitaine, 12, 165-217.

Eichmüller, K. (1985). Die Valdeteja Formation: Aufbau und Geschichte einer oberkarbonischen Karbonatplattform (Kantabrisches Gebirge, Nordspanien). Facies, 13, 45-154.

Enpu, G., Samankassou, E., Changqing, G., Yongli, Z., \& Baoliang, S. (2007). Paleoecology of Pennsylvanian phylloid algal build-ups in south Guizhou, China. Facies, 53, 615-623.

Feng, Q., Gong, Y.-M., \& Riding, R. (2010). Mid-Late Devonian Calcified Marine Algae and Cyanobacteria, South China. Journal of Paleontology, 84, 569-587.

Flajs, G., Vigener, M., Keupp, H., Meischner, D., Neuweiler, F., Paul, J., et al. (1995). Mud mounds: A polygenetic spectrum of finegrained carbonate buildups. Facies, 32, 1-69.

Flügel, E. (2004). Microfacies of Carbonate Rocks: Analysis, Interpretation and Application. New York: Springer.

Forsythe, G. T. W., Wood, R., \& Dickson, J. A. D. (2002). Mass spawning in ancient reef communities: evidence from Late Paleozoic phylloidalgae. Palaios, 17, 615-621.

Groves, J. R. (1986). Calcareous algae and associated microfossils from mid-Carboniferous rocks in east-central Idaho. Journal of Paleontology, 60, 476-496.

Hebbeln, D., \& Samankassou, E. (2015). Where did ancient carbonate mounds grow-In bathyal depths or shallow shelf waters? EarthScience Review, 145, 56-65.

Hensen, C., Dingle, P. \& Schäfer, P. (1995). Primary and diagenetic mud mound genesis in the San Emiliano Formation of the Cármenes syncline (Westphalian B/C, Cantabrian Mts., Spain). In: Reitner, J. \& Neuweiler, F. (eds), Mud Mounds: A Polygenetic Spectrum of Fine-grained Carbonate Buildups. Facies, 32, 1-70.

Ivanova, R. M. (1999). Some calcareous algae from the Carboniferous of the Urals. Paleontologicheskii Zhurnal, 33, 681-685.

James, N. P. (1980). Reef Environments. In: Scholle, P. A., Bebout, D. G. \& Moore, C. H. (Eds), Carbonate Depositional Environments, AAPG Memoir, 33, 346-444.

James, N. P. (1983). Reefs. In: Walker, R. G. (ed.) Facies models geoscience Canada. Reprint series. 1, 121-132

Johnson, J. H. (1963). Pennsylvanian and Permian algae. Colorado School of Mines, Quarterly, 58, 1-211.

Kaufmann, B., Arthur, M. A., Howe, B., \& Scholle, P. A. (1996). Widespread venting of methane-rich fluids in late Cretaceous (Campanian) submarine springs (Teepee Buttes) Western Interior seaway, USA. Geology, 24, 799-802.

Krause, F. F., Scotese, C. R., Nieto, C., Sayegh, S. G., Hopkins, J. C., \& Meyer, R. O. (2004). Paleozoic stromatactis and zebra carbonate mud-mounds: Global abundance and palaeogeographic distribution. Geology, 32, 181-184.

Lambert, L. L. (1986). Growth habitat of the microproblematical genus Donezella in the middle Magdalena, Hueco Mountains, West Texas. Geological Society of America Abstracts with Programs, 18, 250-251.

Lambert, L. L., \& Stanton, R. J., Jr. (1988). Carbonate facies and stratigraphic framework of the middle Magdalena (Middle Pennsylvanian), Hueco Mountains, West Texas. AAPG Bulletin, 72, 101.

Lees, A. (1988). The Waulsortian buildups of the Dinant area. In: Herbosch, A. (ed.), IAS 9th European Regional Meeting Excursion Guidebook Lueven-Belgium, Belgian Geological Survey, 177-185. 
Longman, M. (1981). A Process Approach to Recognising Facies of Reef Complexes. In: Toomey, D. F. (ed.), European Fossil Reef Models. SEPM Special Publication 30, 9-40.

Lotze, F. (1945). Zur Gliederung der Varisziden der Iberischen Meseta. Geotektonische Forschungen, 6, 78-92.

Mamet, B., \& Villa, E. (2004). Calcareous marine algae from the Carboniferous (Moscovian Gzhelian): of the Cantabrian Zone (NW Spain). Revista Española de Paleontología, 19, 151-190.

Mamet, B., \& Zhu, Z. (2005). Carboniferous and Permian algal microflora, Tarmin Basin (China). Geologica Belgica, 8, 3-13.

Martínez Chacón, M. L. \& Winkler Prins, C. F. (1979). The brachiopod fauna of the San Emiliano Formation (Cantabrian Mountains, NW Spain) and its connection with other areas. Compte Rendu du 9ème Congrès sur le Carbonifère, Washington, Champaign-Urbana, 1979. 5, 233-244.

Maslov, V. P. (1929). Microscopic algae from Carboniferous limstones of the Donetz Basin. Akad. Nauk. SSSR, Vsesoyuznii Geologo-Razvedochnii, 40, 1519-1542.

Monty, C. L. V. (1995). The rise and nature of carbonate mudmounds: an introductory actualistic approach. In: Monty, C. L. V. Bosence, D. W. J. Bridges, P. H. \& Pratt, B. R. (eds), Carbonate Mud-Mounds Their Origin and Evolution. International Association of Sedimentologists Special Publication, 23, 11-48.

Monty, C. L. V., van Laer, P., Maurin, A. F. \& Bernet-Rollande, M. C. (1988). The Upper Devonian mud mounds. In: Herbosch, A. (ed), IAS 9th European Regional Meeting Excursion Guidebook Lueven-Belgium: Belgian Geological Survey, 157-176.

Moore, L. R., Neves, R., Wagner, R. H., \& Wagner-Gentis, C. H. T. (1971). The stratigraphy of Namurian and Westphalian rocks in the Villamanín area of northern León, NW Spain. Trabajos de Geología, 3, 307-363.

Neuweiler, F., Bourque, P.-A., \& Boulvain, F. (2001). Why is stromatactis so rare in Mesozoic carbonate mud mounds? Terra Nova, 13, 338-346.

Pérez-Estaún, A., Bastida, F., Alonso, J. L., Marquínez, J., Aller, J., Alvarez-Marrón, J., et al. (1988). A thin-skinned tectonic model for an arcuate fold and thrust belt: the Cantabrian zone (Variscan Ibero-Armorican arc). Tectonics, 7, 517-537.

Pratt, B. R. (1995). The origin, biota and evolution of deep-water mud-mounds. In: Monty, C. L. V., Bosence, D. W. J., Bridges, P. H. and Pratt, B. R. (eds), Carbonate Mud-Mounds Their Origin and Evolution. International Association of Sedimentologists Special Publication, 49-123.

Proust, J.-N., Vennin, E., Vachard, D., Boisseau, T., Chuvashov, B., Ivanova, R., et al. (1996). Sedimentological and biostratigraphical analysis of the Bashkirian stratotype (Southern Urals, Russia). Bulletin des Centres de Recherches Exploration-Production Elf-Aquitaine, 20, 341-365.

Rácz, L. (1964). Carboniferous Calcareous Algae and their Associations in the San Emiliano and Lois-Ciguera Formations (Prov. León, NW Spain). Leidse Geologische Mededelingen, 31, 1-112.

Radig, F. (1962). Ordovizium/Silurian und die Frage Prävariszischer Faltungen in Nordspanien. Geologische Rundschau, 52, 346-357.

Rich, M. (1967). Donezella and Dvinella, widespread algae in Lower and Middle Pennsylvanian rocks in East-Central Nevada and West-Central Utah. Journal of Paleontology, 41, 973-980.

Riding, R. (1979). Donezella bioherms in the Carboniferous of the southern Cantabrian Mountains, Spain. Bulletin des Centres de Recherches Exploration-Production Elf-Aquitaine, 3, 787-794.

Riding, R. (2002). Structure and composition of organic reefs and carbonate mud mounds: concepts and categories. Earth Science Reviews, 58, 163-231.

Samankassou, E. (2001). Internal structure and depositional environment of Late Carboniferous mounds from the San Emiliano Formation, Cármenes Syncline, Cantabrian Mountains, North Spain. Sedimentary Geology, 145, 235-252.
Samankassou, E., Von Allmen, K., \& Bahamonde, J. R. (2013). Growth Dynamics of Pennsylvanian Carbonate Mounds From A Mixed Terrigenous-Carbonate Ramp In The Pueble De Lillo Area, Cantabrian Mountains, Northern Spain. Journal of Sedimentary Research, 83, 1099-1112.

Samankassou, E. \& West, R. R. (2003). Constructional and accumulational modes of fabrics in selected Pennsylvanian algal dominated buildups in eastern Kansas, Midcontinent, USA. In: Ahr, W. M., Harris, P. M., Morgan, W. A. \& Somerville, I. D (eds), PermoCarboniferous platforms and reefs. SEPM/AAPG Special Publication, SEPM/AAPG Special Publication 78, 219-237.

Schmidt, D. U., Leinfelder, R. R., \& Nose, M. (2001). Growth dynamics and ecology of Upper Jurassic mounds, with comparisons to Mid-Palaeozoic mounds. Sedimentary Geology, 145, 343-376.

Shuysky, V. P. (1985). On the position of the Paleoberesellids and other segmented algae from the Siphonophyceae. New data on the Geology, biostratigraphy and paleontology of the Urals. Akad. Nauk. SSSR, Ural, Nauchn. Centr, Inst. Geol. Geochem. Akad 86-95.

Stockmans, F., \& Williér, Y. (1965). Documents paléobotaniques pour l'étude du Houiller dans le Nord-Ouest de l'Espagne. Mémoires de l'Institut Royal des Sciences Naturelles de Belgique, 79, 1-106.

Swennen, R. (1988). IAS 9th European Regional Meeting Abstracts Lueven-Belgium. Belgian Geological Survey, 245.

Termier, H., Termier, G., \& Vachard, D. (1977). On Moravamminida and Aoujgaliida (Porifera, Ischyrospongia): upper Paleozoic "Pseudo Algae". In E. Flügel (Ed.), Fossil Algae-Recent Results and Developments (pp. 215-219). Berlin: Springer-Verlag.

Toomey, D. F. (1976). Paleosynecology of a Permian plant dominated marine community. Neues Jahrbuch für Geologie und Paläontologie Abhandlungen, 152, 1-18.

Toomey, D. F. (1991). Late Permian reefs of southern Tunisia: Facies patterns and comparison with the Capital Reef, southwestern United States. Facies, 25, 119-145.

Vachard, D., \& Cózar, P. (2010). An attempt of classification of the Palaeozoic incertae sedis Algospongia. Revista Española de Micropaleontología, 42, 129-241.

Vachard, D., Perret, M. F., \& Delvolvé, J. J. (1989). Algues, pseudoalgues et foraminifères des niveaux bachkiriens dans les secteurs d'Escarra et Aragon Subordan (Pyrénées aragonaises, Espagne). Geobios, 22, 697-723.

Van De Graff, W. J. E. (1971). The Piedrasluengas limestone, a possible model of limestone facies distribution in the Carboniferous of the Cantabrian Mountains. Trabajos de Geologia, 3, 151-159.

van Ginkel, A. C., \& Villa, E. (1996). Palaeontological data of the San Emiliano Formation (Cantabrian Mountains, Spain) and their significance in the Carboniferous chronostratigraphy. Geobios, 29, 149-170.

Wagner, R. H. (1959). Flora fossil y estratigrafía del Carbonífero de España NW y Portugal N. Estudios Geológicos, 15, 393-420.

Wagner, R. H., \& Bowman, M. B. J. (1983). The position of Bashkirian/ Moscovian boundary in West European chronostratigraphy. Newsletter on Stratigraphy, 12, 132-161.

Watkins, R. (1999). Upper Paleozoic biostromes in island-arc carbonates of the eastern Klamath terrane, California. Paleontological Research, 3, 151-161.

Wiggins, W. D. (1986). Geochemical signature in carbonate matrix and their relation to deposition and diagenesis, Pennsylvanian Marble Falls Limestone, Central Texas. Journal of Sedimentary Petrology, 56, 771-783.

Wilson, J. L. (1975). Carbonate Facies in Geologic History (p. 379). Berlin: Springer.

Wood, A. (1948). "Sphaerocodium", a misinterpreted fossil from the Wenlock Limestone. Proceedings of the Geological Association, 59, 9-22.

Wood, R. (2000). Novel paleoecology of a post extinction reef: Famennian (Late Devonian) of the Canning basin, northwestern Australia. Geology, 28, 987-990. 


\section{Affiliations}

\section{Steven L. Rogers ${ }^{1}[$}

$\triangle$ Steven L. Rogers

s.1.rogers@keele.ac.uk

School of Geography, Geology and the Environment, University of Keele, William Smith Building, Keele, Staffordshire ST5 5BG, UK 